\title{
The Factors Enhancing Work Passion of Family Successors in the Life Insurance Business in Thailand: An Appreciative Inquiry Approach
}

\author{
Wasita Boonsathorn, Ph.D. \\ Associate Professor in the Graduate School of Human Resource Development \\ National Institute of Development Administration (NIDA) \\ 118 Moo 3, Serithai Road, Klong-Chan, Bangkapi, Bangkok 10240, Thailand \\ E-mail:wwasita@hotmail.com
}

\begin{abstract}
Pariwat Sirakiatsakul
Lecturer in the Faculty of Management Sciences, Chiang Mai Rajabhat University 202 Chang Puak Road, Chang Puak, Chiangmai 50300, Thailand

E-mail: pariwat_sir@cmru.ac.th
\end{abstract}

Received: Oct. 11, 2018 Accepted: Dec. 13, 2018 Online published: Dec. 24, 2018 doi:10.5296/ijhrs.v9i1.13759

URL: https://doi.org/10.5296/ijhrs.v9i1.13759

\begin{abstract}
The purpose of this study was 1) to understand the successors' attitude toward working in the insurance business with family members, and 2) to explore the factors that enhance work passion of successors in working collaboratively with their family members in the life insurance business. This study employed qualitative methodology with the use of the appreciative inquiry (4D-Dialogue) approach. Using triangulation of data sources, 36 key informants were recruited, 18 were successors that work with their parents, and 18 were parents of these successors. All of the participants worked together in one life insurance company in Thailand. Data were collected using focus group semi-structured interviews. Content analysis with analytic induction was used as the analytical tool. Trustworthiness was built through data triangulation, member checking, and peer debriefing. The results indicated that, for the first objective, the successors' attitude toward working in the insurance business with their family consisted of four attitudes: 1.1) against; 1.2) unwilling; 1.3) willing, but lost; and 1.4) willing and successful. Regarding the second objective, five factors were found: 2.1)
\end{abstract}


Goals: support of personal goals, help with self-development, enhancing the family happiness, and showing gratitude for family kindness; 2.2) Content: work aligned with expertise or educational background, and work being meaningful; 2.3) Coaching: appropriate coaching strategy, systematic professional coaching strategy, fairness, sharing pride in success; 2.4) Family: encouragement without pressure and caring; and 2.5) Organization: organization's image, favorable work environment, and experience of positive outcomes from the life insurance business. Then, for the Design phrase, the action plan "FAMILY," which comprised of F-Finale with Family; A-Attitude and Ability through Activities; M-Motivating Appropriately; I-Ideal People/Team; L-Leading through Vision/Leading through Coaching; and Y-Yes Club of the future, was offered. To summarize, a 4D-Dialogue for the appreciative inquiry was proposed.

Keywords: work passion, succession planning, life insurance, appreciative inquiry

\section{Introduction}

\subsection{Research Problem}

As family businesses have grown a great deal in today's economy, they have gained a lot of attention, and one of the issues that the family business faces is how to continue and sustain through the generations (Virunhagarun \& Boonsathorn, 2017). Many studies have identified succession planning, the process of identifying and developing leaders for the next generation, as an important factor that leads to the performance, viability, and long-term survival of the family business (Lussier \& Sonfield, 2012; Steier et al., 2009). Because of the special nature of the family business, members might struggle through handling the tasks at hand while maintaining close relationships, which might be challenging at times (Wee \& Ibrahim, 2012). In addition to preparing successors in many ways, for example in terms of education, skills, and creating trusting relationships, enhancing the motivation to work plays a large role in the success of the family business (Mokhber et al., 2017). Virunhagarun and Boonsathorn (2017) have stated that for the family business to succeed, successors' passion is a key factor in determining how committed they will be to the business. Committed successor will put in the time and effort needed to make the company excel, as well as fight through the obstacles they may face along the way. Zigarmi et al. (2016) used the phrase "work passion" to explain employees' positive emotional state of mind that results from perceptions of worthwhile work, autonomy, collaboration, growth, fairness, recognition, connectedness to colleagues, and connectedness to leaders. When employees have passion at work, it results in positive behaviors such as discretionary effort, long-term commitment to the organization, peak performance, low turnover, and increased tenure with the organization.

In the life insurance industry, in addition to attempting to create a customer network, these companies treasure their sales agent teams as a valuable asset. Especially, the life insurance company used in this study, though considered one of the largest life insurance companies in Thailand, has a long history of maintaining a family culture with its employees. The company has a policy of encouraging sales agents to build strong teams as well as to strongly support sales agents to encourage their family members to be successors within the team. The company sees that the sales agents transfer both explicit and tacit knowledge to the next 
generation of family members more easily as mentors than to new hires outside their families. More importantly, successful succession planning will serve the purpose of enhancing trust on the part of customers as they may feel more assured that if the parents passed away, the successors of the sales agents will continue to take care of them. Because the high incentive from the insurance premium can be transferred to the successors, the sales agents usually try to persuade their family members to join the team.

An annual report of the Office of the Insurance Commission (OIC) (2016) indicated a rapid growth trend in the insurance industry. From January to December 2016, the inpremium income of the Thai insurance industry increase by $4.76 \%$. The total direct premium income of the life insurance business saw an increase of $6.52 \%$ and that of the general insurance business an increase of $0.26 \%$ compared with the same period in the previous year. The operational earning of the life insurance business was 661,619 million Baht or an increase of $7.19 \%$, while the total expense was 601,083 million Baht or an increase of $7.18 \%$. As a result, the total operational profit of the life insurance business was 60,536 million Baht or an increase of $7.30 \%$ with a net profit (loss) of 53,829 million Baht and an increase of $7.71 \%$. This increasing growth highlights the opportunities for the insurance business.

Surprisingly, insurance companies in Thailand are encountering a shortage of family successors. This partly stems from how the new generation views insurance agents and the desire to work in a career in the field in which they graduated. In addition, relationship issues with the family when working together worsen the problem. Suwannachot (2008) has proposed some approaches to how to enhance the work motivation of insurance brokers by systematically and flexibly improving the internal operating administration and organizing career development plans, including training and development schemes for insurance brokers and building up motivation for output delivery. This would increase individual satisfaction and reduce employees' turnover accordingly. However, the study focused on the motivation of insurance agents in general. The special case of the relationship situation within family succession planning of insurance teams has remained unexplored.

\subsection{Research Objectives}

This research focuses on exploring the attitudes of family successors toward working with family in life insurance business, and seeks to investigate the factors that might enhance work passion of family successors in the life insurance business. With these two objectives, two research questions are proposed as follows:

(a) What are the successors' perceptions and attitudes toward working in the life insurance business with family members?

(b) What are the factors enhancing work passion for collaborative work between the successors and family in the life insurance business?

\section{Literature Review}

\subsection{Succession Planning}

Businesses today are facing challenges from many changes, such as changes in political 
policies, in the environment, and with society and technology. These rapid changes require adjustment and great energy to survive, and even more, to succeed. In order to create a competitive advantage organizations need to find a way to retain and energize employees. Mehrabani and Mohamad (2011) indicated that succession planning is one of the most practical intervention tools that helps to promote employees' knowledge, skills, talents, and capabilities to tackle problems and serves as a valuable tool to overcome the lack of personnel in critical positions. Succession planning is the process of identifying needed successors to replace their older family members for a specific job. The target of succession planning in this view focuses on top leaders and business owners in large organizations, however, succession planning can be used in many different types of jobs and with different, responsibilities, organizations, and culture (Mehrabani \& Mohamad, 2011).

For family businesses, succession planning is quite different from that of large companies. The number of candidates to be a successor is one of the issues, as in small family-owned firms as candidates are limited to family members (Tatoglu et al., 2008 cited in Mokhber et al., 2016). The management process, such as the criteria for choosing the successor and planning for the final transfer of management, and the expected outcome of the succession in small and medium-sized family businesses, make it more complicated (Van der Merwe et al., 2009). Limchaikul et al. (2018) proposed a five-step learning model called the successor development process of establishment as follows: 1) set goals or objectives for development; 2) assess the need for development; 3) prepare an individual development plan; 4) implement a development plan; and 5) evaluation of development results. Together with the five steps, five components in the new frame of reference were proposed to ensure that the successor gained the essential knowledge and skills in order to work efficiently. The five components included: 1) the success factors of management and succession development; 2) learning styles; 3) action learning; 4) supporting the workplace learning environment; and 5) measuring succession development. The supervisor, human resource personnel, and the successor need to work hand in hand and adjust the development plan for the best fit.

The nature of succession planning differs from organization to organization. The life insurance industry has quite an interesting nature in terms of succession planning management. Both teams and customer networks, can be transferred to the successors in line. The perception of ownership and the attitude of the next generation toward the parents' insurance business, including the career itself, sometimes are negative. The new generation often prefers to pursue its career in line with the study focus in university. Thus, strengthening a positive work attitude and enhancing the passion to work in the insurance industry are vital for increasing operating efficiency. The transfer of the business to next generation not only benefits the parents and the company, but also the customers in the form of the continuity of the service. These benefits will occur fully if the family successors take over the business with passion to work.

\subsection{Passion}

The term passion has been used in many contexts with both negative and positive connotations. However, the meaning is quite abstract. Zigarmi et al. (2009) came up with the 
phrase "employee work passion" and created a work passion model to help make the term more concrete and readily applied. They provided a clear definition of work passion. When people have a positive attitude or evaluate the environment using cognitive and affective aspects, it will result in five behavioral intentions: 1) intent to stay with the organization; 2) organizational commitment; 3) job commitment; 4) discretionary effort; and 5) employee endorsement. Work passion has 2 prospects - harmonious passion and obsessive passion (Gorgievski, \& Bakker, 2010).

Zigarmi et al. (2016) developed the "model for employee passion" and found that employee passion is a positive emotional state of mind resulting from the perceptions of eight key factors influencing employee passion as follows: 1) meaningful work; 2) collaboration; 3) fairness; 4) autonomy; 5) recognition; 6) growth; 7) connectedness with leader; and 8) connectedness with colleagues. These factors lead to behaviors that include discretionary effort, long-term commitment to the organization, peak performance, low turnover, and increased tenure with the organization. When employee passion is maximized, it in turn leads to devoted customers, which results in sustainable growth, profits, and higher stock value, as shown in Figure 1 below.

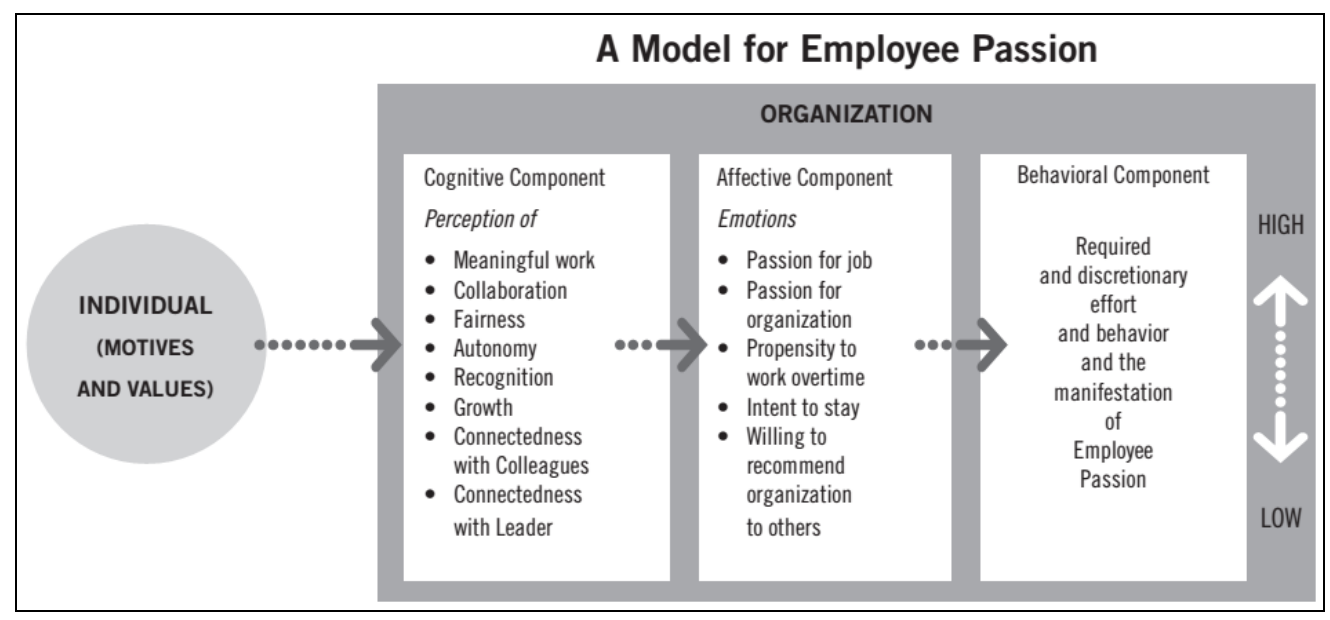

Figure 1. A Model of Employee Passion

Source: Employee Passion (Zigarmi et al., 2016)

If an organization understand how enhance work passion, it would lead to higher sustainable employee's performance. Studies regarding work passion have been conducted on many types of business. Nonetheless, enhancing employee work passion in the life insurance industry, especially in the aspect of family successors, has not been investigated. Therefore, this study examines the attitudes regarding work in life insurance business with family members in Thailand and explores the factors that enhance passion in the collaborative work between the successors and the family in the life insurance business in Thailand using the appreciative inquiry (AI) framework.

\subsection{Appreciative Inquiry (AI)}

Cooperrider and Whitney (2005 quoted in Rattanaphan, 2010) explained that appreciative 
inquiry (AI) is a tool for organization development that based on asking positive questions. Focusing on strength and best practice, the whole-system 4-D Dialogue model can be established. The model utilizes a cycle of four processes involves: 1) Discovery - the identification of the best processes that work well; 2) Dream - the envisioning of processes that would work well in the future; 3) Design - planning and prioritizing what would work well; and 4) Destiny - the execution of the prosed design. For this study, AI was employed as a key approach in order to examine the two research questions proposed. This can be a guide for developing successors in the succession planning process in the life insurance business for the next generation. The Process of the Whole-system 4-D Dialogue is shown in Figure 2 below.

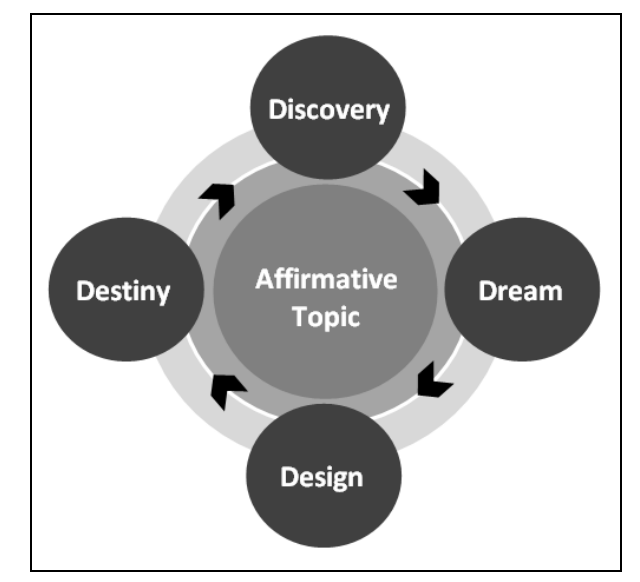

Figure 2. Process of Whole-system 4-D Dialogue

Source: Adapted from Cooperrider and Whitney (2005)

In Thailand there is a group of researchers under the team AI Thailand, headed by Dr. Pinyo Rattanaphan, who has conducted research using the AI approach to developing organizations and human potential. The research has had a great impact in many areas, such as the organizational development in auto parts stores (Ruangchaijatuporn, Petkam, \& Rattanaphan, 2012), in improving the customer's experience in the pharmaceutical context (Manoonwong, \& Rattanaphan, 2012), in increasing employee engagement in a resort and a mansion (Dansiri, \& Rattanaphan, 2012), and in facilitating the succession planning of a hill tribe community in the northern part of Thailand (Pliansiri \& Boonsathorn, 2015). This study seeks to expand AI to facilitate family succession planning in the insurance business, which is very unique.

\section{Methodology}

\subsection{Data Collection}

This qualitative study used appreciative inquiry method (4D-Dialogue) for the data collection and modeling design. Focus group interviews were conducted. At the beginning of the session, the participants were asked to draw a picture of their perception of their current work with their parents in the insurance company, followed by semi-structure interviews, ending with the individuals' envisioned dream of the ideal workplace with the family. The process of appreciative inquiry was used throughout the interviews and data analysis. 
Data was collected from 36 key informants in a leading Thai life insurance company, including 18 successors that collaboratively worked in the life insurance business with family, and 18 successors' parents that were in the same business area. The participants were selected from the company's sales agents that had demonstrated great performance and had sent their potential successor to the company's program, called the Yes Club, a program to groom the successor in terms of attitudes and motivation to work with his/her parents in the life insurance business. The program is organized once a year and is tailored made with activities mainly to prepare the successors' mindset. The successors were those that had joined the Yes Club in different batches. Two groups of key participants are illustrated below.

Table 1. Groups of key informants

\begin{tabular}{|c|c|c|c|}
\hline $\begin{array}{c}\text { Key } \\
\text { Informants }\end{array}$ & Gender & $\begin{array}{l}\text { Age I } \\
\text { years }\end{array}$ & Group \\
\hline \multirow{2}{*}{ successors } & Female (11) & $21-31$ & \multirow{4}{*}{$\begin{array}{l}\text { G1 - successors (12) } \\
\text { G2 - successors+parents who collaboratively work (12) } \\
\text { (from the same family) } \\
\text { G3 - parents (12) }\end{array}$} \\
\hline & Male (7) & & \\
\hline \multirow[t]{2}{*}{ parents } & Female (9) & $45-64$ & \\
\hline & Male (9) & & \\
\hline Total & 36 persons & & \\
\hline
\end{tabular}

\subsection{Data Analysis}

The qualitative content analysis technique was used for the data analysis. In order to enhance trustworthiness, many approaches were employed. In terms of credibility, two researchers attended the interview session-one conducted the interviews and the other one observed the behavior of the participants. Member checking was used throughout the interviews and peer debriefing was conducted. Two researchers analyzed the data independently then returned for a discussion to reconcile the findings together at the end. For confirmability, the interview sessions were recorded in audio format. The researchers selected actual statements for accuracy and supported the findings with direct quotations. The study employed data triangulation by cross-checking the data from the 3 groups of key informants during the focus group interviews, including the successors only group, the successors+parents group (from different family), and the parents only group. Methodological triangulation was also employed by using various methods such as focus group interviews and projective method of pictures drawing.

\section{Results}

The results of this study were classified into 2 sections. The first section was responding to 2 research questions. The second section revealed the process of enhancing passion in collaborative work between successor and family through AI model.

\subsection{Section 1: Research Questions}

4.1.1 Research Question 1: What are the successor's perceptions and attitude toward working in life insurance business with family members?

The findings indicated that the successor's perception and attitudes toward working in the life insurance business with family could be categorized according to the following: 1) against; 2) 
unwilling; 3) willing, but lost; and 4) willing and successful.

\subsubsection{Against}

This perception can be described as the state of the successor's feeling of dislike and avoiding working in the life insurance business with family. If they were forced to do it they would resist and argue with their parents. The successor graded the level of attitude toward working with his/her family in the range of $0-10 \%$ regarding the willingness to work as a successor to the business. One of the participants drew the picture of a lion and a cat and described their feeling about working with his parents as follows.

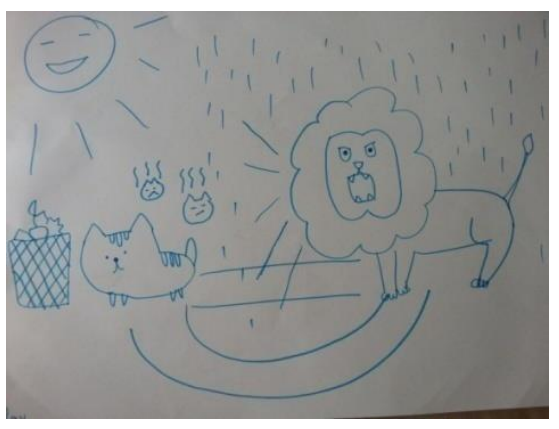

"My father is like a lion. He growls at me like a lion growling at a cat all the time. Working with dad will make me rich. Since the beginning, I hate working in this business so much ...eventually I had to work in the insurance business. I used to think that this type of job was like a garbage can. I never want to eat food from a garbage can but, at last, I had to anyway."

\subsubsection{Unwilling}

This perception happens when the successors relatively begin to open up their minds and accept the work, but there is no passion for the work in the life insurance business with their family. The successors rated their level of attitude toward working with their family in the range of $11-50 \%$. One of the participants explained that working in this business with her parents was like she was stuck behind a wall. She knew that there was a way out, but she didn't know how. She described her feelings in the picture and quote below.

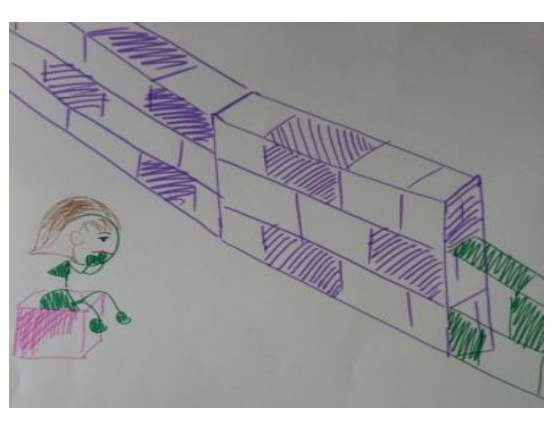

"It was interesting to know how people in the insurance business can spend a lot of money without worrying. When I found out how they earned the money, I was eager to go into the business. I would like to use the money earned to invest in other businesses. I decided to join. At first, it was fun because I got some customers. Afterwards, there were no customers, and I had no idea who I should offer the product to. Then, I got struck."

\subsubsection{Willing, but Lost}

This perception happens when the successors feel positive about the life insurance business and intend to help the family with work passion toward the business. Nonetheless, because of a lack of support, coaching, and assistance for the successor from both the family and the organization, the successor's passion goes up and down. They rated the level of willingness to work with their family in the range of $51-80 \%$ as the following quote describes. 


\section{Macrothink}

International Journal of Human Resource Studies

ISSN 2162-3058 2019, Vol. 9, No. 1

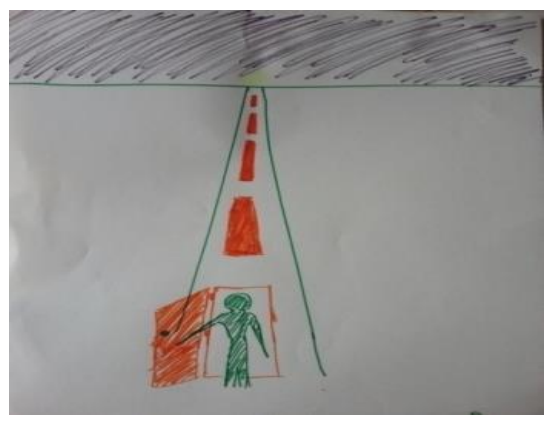

"I decided to follow this path. I open the door and am ready to walk in, but I see a big wall at times. I want more guidance from my parents."

\subsubsection{Willing and Success}

This perception happens when the successors feel valued, loved, and are willing to work with passion toward the life insurance business with their family. Support, coaching, and assistance are provided for the successors from both the family and the organization. The successors rated the level of attitude toward working with their family in the range of $81-100 \%$ as follows.

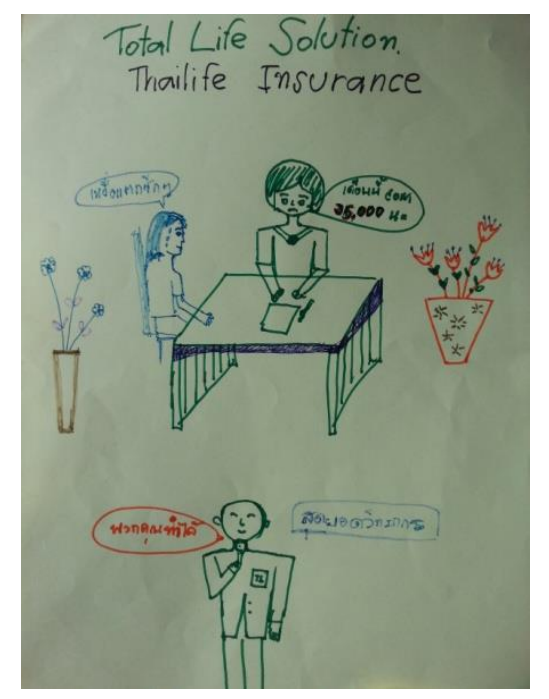

"I never know that my dad was so great. But everyone tells me how great he is. It's like eye lashes that are so close, but you can't see them. I want to be like my dad."

"The Yes Club gave me knowledge and the understanding that the insurance business was a kind of job that could help society."

"This job could fulfill my life such as income, flexibility, and helping others."

4.1.2 Research Question 2: What are the factors enhancing passion in collaborative work between successor and family in life insurance business?

The findings revealed that each group of successors had different perspectives about working in the life insurance business with their family. There were four major factors enhancing the passion about collaborative work between the successor and his or her family, as follows.

\subsubsection{Group of "Against" Attitude}

When asking to reflect on the times that they felt passionate about their work, the successors from this group reported that their passion occurred from or because of a lack of the following factors: 1) work aligned with expertise or educational background; 2) fairness; 3) encouragement without pressure; 4) caring; 5) organization's image; and 6) experience of positive outcomes from the life insurance business, as follows. 
4.1.2.1.1 Work aligned with expertise or educational background. This is the desire to work in the same field as that from which the individual graduated, as seen in the statement below.

"I wouldn't like to be in insurance business. I wanted to work in the area that related to my degree then become a private company employee, a government officer, a personal business owner or a traveler to gain more experience."

4.1.2.1.2 Fairness. The participants would have more passion to work if the incentive and compensation were distributed fairly, while working with family, as indicated below.

"My father was my boss and he kept the budget such as related events and transportation costs. He got the money in advance, and when I needed it, there was nothing left. If he had distributed fairly as promised I would be more willing."

4.1.2.1.3 Encouragement without pressure. Constructive communication to reinforce, sympathize, and reduce pressure from incomplete tasks would increase passion as shown below.

"I put in a lot of effort, unfortunately something was wrong. I got yelled at like "just managing the team, you couldn't handle... stupid... I, a mother, coped with it for 8-9 years without any issues. Once you were in charge, problems came up so you were not requested to be involved."

4.1.2.1.4 Caring. This issue focused on how parents can spend time and give consultation to the family, rather just offering money. Proper attitude toward the parents' career can be improved because the parents give all of their time to the insurance business and had no time for the successors when they were children. One of the parents stated the following in connection with how caring is of great importance to passion to be a successor more than just giving the money.

"The kids were not aware of how much I provided them. I, as a father, was a true giver. Whatever they wanted, I did my best to give them but there was just not enough time to spend with them. ... I wanted them to understand the worth of money and how hard they could earn, even a small amount. I continually offered the money-that was a real mistake. A lot of parents did the same way because getting money from life insurance business is easy. I accepted that the new generation was reluctant to listen to what I taught. Sometimes, I got angry and it back fired."

4.1.2.1.5 Organization's image. The successors felt that when their friends knew that they worked in the insurance business, their friendship kind of deteriorated. The image of being in insurance business reduced the passion to work, as can be seen in the statements.

"Presently, my friends don't like to talk to me. They believe that I would sell them a life insurance package; therefore lots of friends ceased our connection."

4.1.2.1.6 The experience of positive outcomes from the life insurance business. When the parents pointed out how the money from insurance business helped the financial situation of the family, the children opens up to be a successors, as quoted statements.

"When I was a kid, mom continuously had no time and I knew that she was so fatigued. So I 
didn't want to do this career. However, my mother said that the money that we spent in our daily life was always sufficient because of this job. Thus, I tried to be open."

\subsubsection{Group with an "Unwilling” Attitude}

For this group, passion occurred from 1) support of personal goals; 2) showing gratitude for the family's kindness; 3) work being aligned with expertise or educational background; and 4) a favorable work environment, as follows.

4.1.2.2.1 Support of Personal Goals. When the successors felt insurance business provide flexibility that come with good income that allows them to do additional things they love, passion increased. The money they made from insurance business can be extended to invest in any other business, or to follow one's personal goals, as can be seen in the following quote

"I intended to build up my team in order to have time for doing other beloved jobs. I was managing 3-4 businesses."

4.1.2.2.2 Showing gratitude for the family's kindness made the insurance business a great chance to repay the parents' kindness by working in this profession, as seen below.

"My mother never forced me to be a successor, but let me think on my own. I used to see my mother reading an insurance manual, and when going to meet customers she also took me there. Until now, mom doesn't know how to use a computer to support her job and I also started helping her. I asked my mom if she were exhausted. She said 'No, I am fine.' I could put everything on my shoulders but she had to be alright. I was not ashamed at all to tell others that my mother was an insurance broker."

4.1.2.2.3 Work being aligned with expertise or educational background refers to the passion that occurs when the successors feel that they can apply their knowledge from school to their work, as seen in the following quoted statement.

"Firstly, I closed my mind with this job and was unwilling to do it. After attending the YES Club, I tended to be more open and applied the knowledge to my job based on the statement of a top manager: "After graduation, you have a wider opportunity of jobs to choose from more than others."

4.1.2.2.4 Favorable work environment. Successors desired not only a favorable work environment but also a decreasing number of meetings as well as colleagues' sincerity was expected, as seen in the following.

"I really hated the insurance business as there were lots of meetings. The work environment was also fake. My colleagues smiled and talked nicely, but they gossiped behind my back. It was terrible and awful."

\subsubsection{Group of "Willing but Lost" attitude}

For this $3^{\text {rd }}$ group, passion occurred from: 1) support of personal goals; 2) enhanced family happiness; 3) showing gratitude for the family's kindness; 4) an appropriate coaching strategy; 5) sharing pride in success; and 6) a favorable work environment, as can see in the following. 
4.1.2.3.1 Support of personal goals. Passion occurs when realizing that this career earns a good income, then extends to investment in any other businesses or following personal goals, as in the following statement.

The money earned from selling insurance was invested in personal business in order to fulfill my dream.

4.1.2.3.2 Enhanced family happiness. It is personal aim to work in the insurance business for travelling with one's family because the family happiness is the ultimate goal, as stated in the following.

I would like to win a competition, have my own house, and create happiness for all my family members by myself.

I targeted taking every family member to travel abroad altogether.

4 1.2.3.3 Showing gratitude for the family's kindness. This feeling of gratitude strengthens the desire toward the insurance business because of the intention to gratify the family by helping parents do the business, as stated in the following.

Working in the insurance business could rescue us from family crisis, and also show gratitude to our parents.

4.1.2.3.4 Appropriate coaching strategy. When the parents coach the new generation by separating personal and work matters, acting as role models, and communicating in appreciative and creative ways, the successors feel the passion toward working in the business, as expressed in the following.

Teaching was to make me visualize, but did not just simply say wordslize, but it didy withsome allu did not. For instance, did you go to meet customers yet ... where were my customers? / Let's visit existing customers and try to build up further business relations. Unfortunately, they never taught me how to concretely build up the business. When meeting customers, what would be the next step for my action?

Parents like to compare. They asked why others could get it done, but not me. That was a strong pressure on me / I was not that person, was I? / Pressure with positive reinforcement could be an option, like "Hey, many people went to Japan. Did you like to go there? If so, should we reach the sales target by helping each other to achieve it?" Some type of psychological encouragement should be taken into account. My parents just talked to me like one of their employees. / One more thing "Why didn't you do that, why didn't you do this. Looking at others, why you did not behave like that?"

4.1.2.3.5 Sharing in the pride in success. To create an opportunity for successors to participate in the success and to increase their motivation from collaborative work achievement, and to help create passion, as stated in the following.

When we go out on exhibition, if we could sell, mom gave all the money to me. This would make me have a sense of accomplishment.

4.1.2.3.6 Favorable work environment. Work is more desirable when there is a sincere 
environment among colleagues, as stated in the following.

Entering into the company, it could be noticed that the colleagues gossiped with each other. This was common in every department.

\subsubsection{Group of "willing and successful" attitude}

It was discovered that passion occurred by: 1) helping with self-development; 2) work being meaningful; 3) having a systematic professional coaching strategy; 4) fairness; 5) sharing in the pride in success; and 6) experiencing positive outcomes from the life insurance business, as stated in the following.

4.1.2.4.1 Help with self-development. It has good attitude toward insurance business seen from parents who are the role model that enhanced passion. When seeing the parents overcame challenging work to reach target, the successors felt they wanted to develop themselves, as quoted statements.

My parents were my role model as "their real practice was valuable more than any verbal instruction." They collected some assets for me; in fact I believed that the assets actually belonged to them. I worked in this business because I would like to grow by myself. I was confident that everyone could be improved. Firstly, I studied chemistry because I wanted to be isolated. At present, I am working in this area and am developing on my own to become successful or to have a further chance to do things that I like. / I was a life planner who helped in designing financial plans as a sort of definite guarantee.

My personal motivation - it was proved by my father's success. I was proud that people called him a teacher. I would like to be like my father who held the respect and care of others. / Money matters were not a big deal.

4.1.2.4.2 Work is meaningful. When feeling that the insurance business is beneficial for the society, passion for the work increased. This kind of service career requires specific knowledge and some types of belief in its dignity to be accepted by the society. This leads to work motivation and patience toward any difficulties, as seen below.

"This job, you could help others. I have worked with the company for ten years. Customers asked me whether I ever took photos with the owner. Yes Club boosted up my knowledge with regard to the insurance business, a kind of work the up lifting society."

"Be patient with difficulties and be clear about what you are selling were major drives. Moreover, understanding the true meaning of your work served as a solid fundamental of self-confidence when explaining to friends about what you do. I believe that the most wonderful offering which they needed but not yet aware of in life insurance. The most terrible issue of the business was that sales persons concentrated too much on sales at all time. They would like to earn commission, but they lacked caring, service attitude, and information.

4.1.2.4.3 A systematic professional coaching strategy. When the parents learned to coach with proper strategies, learned to listen, and learned to use positive communication, it leads to passion to 
be successors. Being flexible in the way of thinking and decision-making, establishing working team would also enhanced passion to join the business. As such, parents need to treat, assist, and teach children in the same manner as one of the team members, not family members, as quoted below.

"Mother listened without any pressure. For example, when coming back from customer visits mom did not yell at me. She just asked to have meal together and that was helpful to relieve my tension and encouraged me for better visits the next day: "If someone buy the insurance, it was unusual, but if you could not sell, it was normal. I had no stress then moved forward for new cases" - Listen with appreciation helped.

Working together for the first visit, my son could shadow my deal. For the second time, he could also see and support me if needed. This practice would avoid losing the relation and ensure how to handle the customer properly. If he acted alone, anything that happened was likely to lose the customer. Parental networks were very valuable. The customers relied on parental maturity and trusted them; therefore, they purchased accordingly.

4.1.2.4.4 Fairness. This is the fair allocation of benefits from working with the family in accordance with work output or motivating by letting them see the amount of income that over their expectations, as seen in the following statements.

Let him get money by himself and he would know how much he got. Separated account of the insurance income from other income. Money would pass on his hands. He would realize the actual amount of his income, which was higher than a full-time office job. He, then, would be active automatically.

I take care of my son like my subordinate. I dressed up and went out from home. He was an insurance broker. During office meetings or coaching work tasks, I treated, taught, and dealt with him in a different status. I coached, taught operating techniques, suggested for team-building. His income was his, not mine. I continually gave extra a bonus for him. I emphasized that even if we worked hard and earned lots of money, we still lived a simple life style as it was. My mother, she was a team builder, not an insurance broker. She collected groups of teams, and earned from team commissions which we had groomed. Working as friends was our idea.

4.1.2.4.5 Sharing in the pride in success. This is a top-up way of success by introducing children to existing customers of parents. Wishing parents to be a part of the children's success is ultimate, as quoted below.

Making the customer felt assured by introducing our children to them make them rest assure that if I, as in insurance broker not available for them, my children would take care of the them regarding the insurance claims and other related things. I hence brought my kids to meet nearly all of my customers.

It was heritage parents make their whole life time to pass on to the next generation. It would be a terribly pity if the children did not take it over. This heritage would be allocated to other insurance brokers. At last, you would not be eligible to reap the benefit at all. 


\section{$\triangle$ Macrothink}

International Journal of Human Resource Studies

ISSN 2162-3058 2019, Vol. 9, No. 1

Wishing to be on stage for a trophy, I would like to see my parents' happy tears on this prestigious day.

4.1.2.4.6 Experience of positive outcomes from the life insurance business is a warm experience from parental raising, where some part of the income is derived from the insurance business. This strengthens good attitudes toward working in the insurance business, as seen in the following statement.

Perhaps, I would like to tell everybody what I had today came from the insurance business. I would not deny that I could finish my study, some part of it from this business. I entered this career because of gratitude to my mother.

\subsection{Section 2: Process of Enhancing Passion and Collaboratively Working Between the Successor and the Family Through the AI Model}

The study of creating passion for family succession planning in life insurance industry through Appreciative Inquiry (AI) intends to analyze and investigate the issue under AI model (4D-Dialogue) - discovery, dream, design, and destiny. The 4 process of enhancing work passion for successors using AI Model are elaborated follows:

\subsubsection{Discovery}

With respect to discovery, it can be reported that the successor's attitude toward the life insurance business with his or her family is comprised of four states: 1) against; 2) unwilling; 3) willing, but lost; and 4) willing and success. The five factors enhancing passion in collaborative work can be summarized as shown in Table 2.

Table 2. Summary of the factors enhancing passion about collaborative work between the successor and family

\begin{tabular}{|c|c|c|c|c|}
\hline \multirow{2}{*}{$\begin{array}{c}\text { Factors enhancing work } \\
\text { passion }\end{array}$} & \multicolumn{4}{|c|}{ Attitude } \\
\hline & $\begin{array}{l}\text { Against } \\
(0-10 \%)\end{array}$ & $\begin{array}{l}\text { Unwilling } \\
(11-50 \%)\end{array}$ & $\begin{array}{l}\text { Willing, but Lost } \\
(51-80 \%)\end{array}$ & $\begin{array}{c}\text { Willing and } \\
\text { Success }(81-100 \%)\end{array}$ \\
\hline 1.1 Support of personal goals & & 1. Goal & 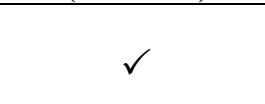 & \\
\hline $\begin{array}{lll}1.2 & \text { Helping } & \text { with } \\
\text { self-development } & \end{array}$ & & & & $\checkmark$ \\
\hline $\begin{array}{l}1.3 \text { Enhancing family } \\
\text { happiness }\end{array}$ & & & $\checkmark$ & \\
\hline $\begin{array}{l}\text { 1.4 Showing gratitude for } \\
\text { family kindness }\end{array}$ & & $\checkmark$ & $\checkmark$ & \\
\hline
\end{tabular}

2.1 Work aligned with expertise or educational background

2.2 Work being meaningful

3.1 Appropriate coaching strategy 3.2 Systematic professional coaching strategy

2. Content

3. Coaching 


\begin{tabular}{|ccccc}
\hline $\begin{array}{c}\text { Factors enhancing work } \\
\text { passion }\end{array}$ & \multicolumn{3}{c}{ Attitude } \\
\cline { 2 - 5 } & $\begin{array}{c}\text { Against } \\
(0-10 \%)\end{array}$ & $\begin{array}{c}\text { Unwilling } \\
(11-50 \%)\end{array}$ & $\begin{array}{c}\text { Willing, but Lost } \\
(51-80 \%)\end{array}$ & $\begin{array}{c}\text { Willing and } \\
\text { Success }(81-100 \%)\end{array}$ \\
\hline 3.3 Fairness & $\checkmark$ & & & $\checkmark$
\end{tabular}

3.4 Sharing the pride in success

4.1 Encouragement without pressure

4.2 Caring

5.1 Organization's image

5.2 Favorable work environment

4. Family

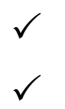

$\checkmark$

5. Organization

5.3 Experience of positive outcomes from life insurance business

\subsubsection{Dream}

According to the key informants' interviews, the ultimate dream in the life insurance business of both parents and successor were to attend "prestigious day", a day to present a trophy for successful insurance brokers in life insurance business. For the successors, the aimed for life achievement, personal pride, and family participation was to go up on stage to receive the trophy with their parents. The pictures of current attitude and the envisioned dream are shown in Table 3.

Table 3. Current attitude and dream for the future

Attitude $\quad$ Picture of current attitude $\quad$ Envisioned dream

1. Against
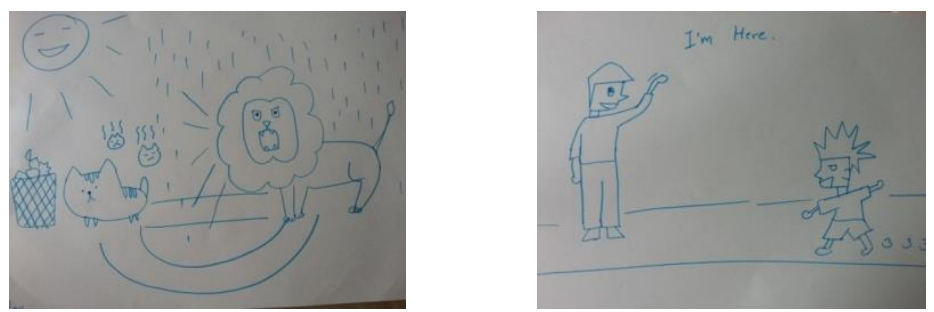

2. Unwilling
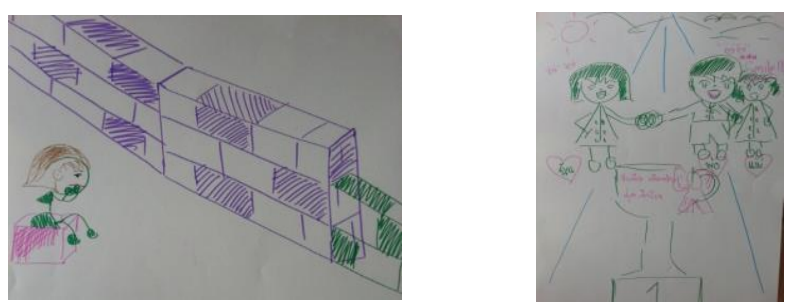
Attitude

Picture of current attitude

Envisioned dream

3. Willing, but Lost
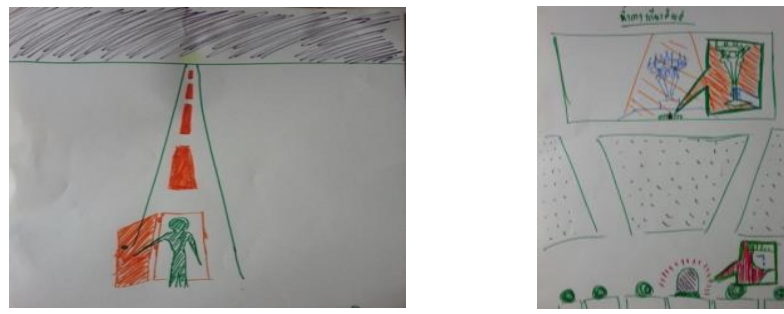

4. Willing and Success
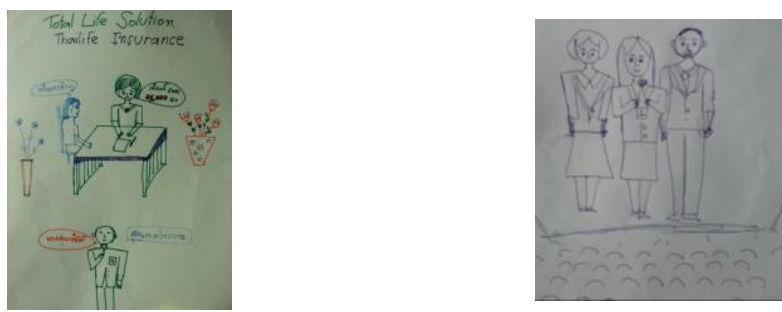

The results shown in table 3 revealed the gap between the discovery and the dream process. Design phrase in the next section would elaborate how the gap can be reduced by incorporating the summary of the results of research question 1 into the model.

\subsubsection{Design}

The researchers proposed the design phase of creating team passion for family succession planning in the life insurance industry through appreciative inquiry by designing courses of actions and activities for successor and parents by summarizing the action plan into "FAMILY" model as follows:

(a) F- Finale with family: Provide mutually-collaborative achievement award that let the successors go up on stage with their family members.

(b) A- Attitude and ability through activities: Design meaningful and exciting training courses and activities for family and successors. The activities should focus on strengthening positive attitudes and improving essential skills in the insurance business, such as communication, team building, sales, personality, and goal-setting.

(c) M- Motivating appropriately: Provide challenging and movtivating compensation together with conducting coaching session using positive communication. This would enhance passion for collaborative work, reasonable goal-setting, and success for both parents and successors.

(d) I- Ideal people/team: Develop role model and ideal working teams. The successors are looking up to their role models. The role model could be their parents, family members, or people in the team in the company. Showing them best practices from successful insurance broker's and teams would inspire passion and lead to achievement.

(e) L- Leading through vision/Leading through coaching: Be a good leader with practical vision and business strategies, including systematic coaching of the successors. To cascade 


\section{N Macrothink}

International Journal of Human Resource Studies

ISSN 2162-3058

2019, Vol. 9, No. 1

clear vision and strategy, the working team should visualize goal as well as support collaborative work results. Managing successors through professional coaching strategies, which differs from the typical parental guidance, is also imperative.

(f) Y- Yes Club of the future: Create and enhance networks for the successors such as "Yes Club", the club that gathers successors from different walks of life together, help create society and supporting group environment needed to maintain and boost passion.

\subsubsection{Destiny}

To put the design process of "FAMILY" above into practice, the insurance company would be taking control of the destiny process. The company would plan the execution of the prosed design by prioritizing what should be done to inspire enhance passion for successors to join the insurance business and achieve their goals.

The results can be summarized into the AI 4D Model in Figure 3 below.

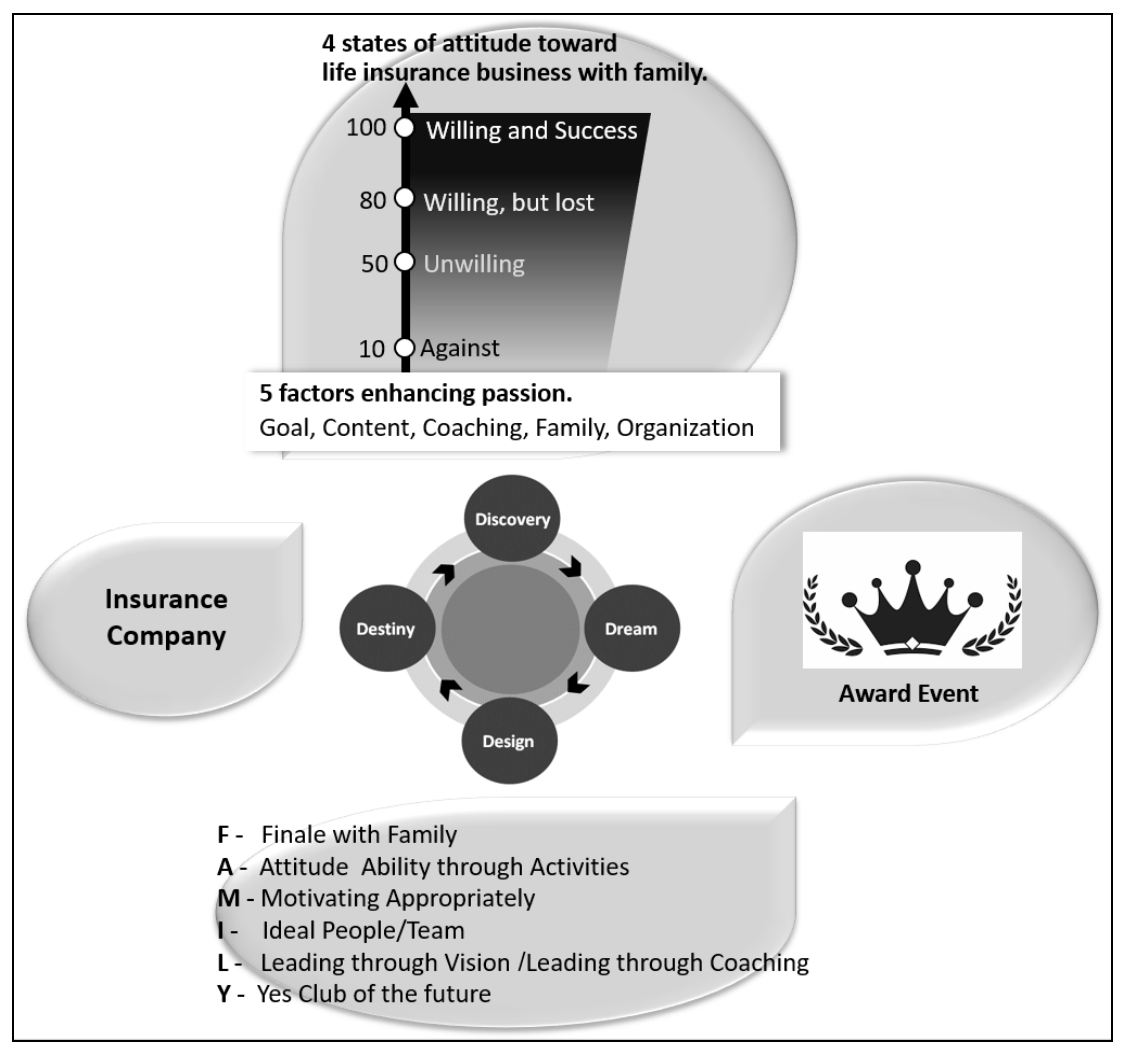

Figure 3. Results shown in the 4D Model

\section{Conclusion and Discussion}

This study focused on problem developing successors in the process of succession planning by improving knowledge, skills, talents, and capabilities in challenging circumstances (Mehrabani, \& Mohamad, 2011). In order to design succession planning in the family-owned context, it is mandatory to adapt the process so that it is aligned with the different natures of each business circumstance (Mehrabani, \& Mohamad, 2011). As such, it was essential to identify the successor because there is a wide impact on team work, group conflict, and work 
motivation (Tatoglu et al., 2008 cited in Mokhber et al., 2016). Nonetheless, for this particular case study, the life insurance company was in need of new generation of insurance brokers. This study highlighted the understanding of the successors' attitudes toward the insurance business which were: 1) against; 2) unwilling: 3) willing, but lost; and 4) willing and successful. It also elicited five factors enhancing the passion for collaborative work with family, which were Goals, Content, Coaching, Family, and Organization (Virunhagarun, \& Boonsathorn, 2017; Zigarmi et al., 2016). The findings pointed out that to enhance the passion of the new generation to work in the insurance business. The insurance company could systematically develop the successor for business transfer from the findings. The study of Steier et al (2009) also supported these findings - that one of the most critical processes in the performance and long-term survival of the family business is the passage in succession. The "FAMILY" model needs to be implemented in order to create passion for successors to be in the insurance business with commitment for the long-term success of the family, the organization, and customers.

\section{References}

Dansiri, W., \& Rattanaphan, P. (2012). The integration of Appreciative Inquiry and Positive Psychology to Increase Employee Engagement: A Case Study of Taweesup Resort Nakhon Ratchasima and Taweesup Mansion Udonthani. In AI Summit Thailand: Leveraging Positive Change for Organization Development and Transformation in Thailand, February 27-29, 2012 at Graduate School of Business, Assumption University of Thailand.

Gorgievski, D., \& Bakker, A. (2010). Passion for work: Work engagement versus workaholism. In S.L. Albrecht (Ed.), Handbook of employee engagement: Perspectives, issues, research and practice (pp. 264 - 271). Glos, UK: Edward Elgar. https://doi.org/10.4337/9781849806374.00030

Limchaikul, S., Kongjareon, M., \& Boriboon, G. (2018). Development of a Learning Model for the Successor Development Process of Establishment. Panyapiwat Journal, 10(1). 196-208.

Lussier, R. N., \& Sonfield, M. C. (2012). Family Businesses' Succession Planning: a Seven-Country Comparison. Journal of Small Business and Enterprise Development, 19(1). 7-9. https://doi.org/10.1108/14626001211196370

Manoonwong, T., \& Rattanaphan, P. (2012). Applying Appreciative Inquiry to Improve Customer Experience: the Case Study of Klangya Kranuan Pharmacy. In AI Summit Thailand: Leveraging Positive Change for Organization Development and Transformation in Thailand, February 27-29, 2012 at Graduate School of Business, Assumption University of Thailand.

Mehrabani, E. S., \& Mohamad, A. N. (2011). Succession Planning: A Necessary Process in Today's Organization. International Journal of e-Education, e-Business, e-Management, and e-Learning, 1(5). 371-377.

Mokhber, M., Tan, G. G., Rasid A., Vakilbashi, A., Zamil, M. N., \& Seng, W. Y. (2017). Succession Planning and Family Business Performance in SMEs. Journal of Management Development, 36(3). 330-347. https://doi.org/10.1108/JMD-12-2015-0171 


\section{Macrothink}

International Journal of Human Resource Studies

ISSN 2162-3058

2019, Vol. 9, No. 1

Office of Insurance Commission. (2016). Annual Report. Retrieved July 19, 2017 from http://www.oic.or.th/sites/default/files/publication/files/phaasaaangkrs.pdf

Pliansiri, P., \& Boonsathorn, W. (2015). The Succession Planning Process Development of the Leaders in Ethnic Community through Appreciative Inquiry (AI). NIDA Development Journal, 55(3). 59-86.

Rattanaphan, P. (2010). Impact of Organizational Development Interventions on Human Capital: A Case Study of Thailand Appreciative Inquiry Network. AU-GSB e-JOURNAL. 3(September). 33-44. Retrieved July 19, 2017 from http://gsbejournal.au.edu/GP/Publication1/4.pdf

Ruangchaijatuporn, T., Petkam, R., \& Rattanaphan, P. (2012). Applying Appreciative Inquiry on Organization Development: a Case Study of Yasothornmitkonkarn Auto Part Store. In AI Summit Thailand: Leveraging Positive Change for Organization Development and Transformation in Thailand, February 27-29, 2012 at Graduate School of Business, Assumption University of Thailand.

Steier, L. P., Chua, J. H., \& Chrisman, J. J. (2009). Embeddedness perspectives of economic action within family firms. Entrepreneurship Theory and Practice, 33(4). 1157-1167. https://doi.org/10.1111/j.1540-6520.2009.00338.x

Suwannachot, P. (2008). Strategies for maintaining a life insurance agent Case Study Muang Thai Life Assurance Co., Ltd (Independent Study of Master of Business Administration, University of the Thai Chamber of Commerce, Bangkok).

Van der Merwe, S. P., Venter, E., \& Ellis, S. M. (2009). An Exploratory Study of Some of the Determinants of Management Succession Planning in Family Business. Management Dynamics, 18(4). 2-17.

Virunhagarun, N., \& Boonsathorn, W. (2017). Work Passion for Successors in SMEs Family Businesses. NIDA Development Journal, 57(1). 245-276.

Wee, Y. G., \& Ibrahim, M. D. (2012). Family business success factors: management practices, relationship among members and succession experience. International Journal of Arts and Commerce. 1(6). 262-274.

Zigarmi, D., Houson, D., \& Witt, D. (2016). Employee Passion. Perspective. UK: The Ken Blanchard Company.

Zigarmi, D., Nimon, K., Houson, D., Witt, D., \& Diehl, J. (2009). From Engagement to Work Passion: A Deeper Understanding of the Work Passion Framework. Perspective. UK: The Ken Blanchard Company.

\section{Copyright Disclaimer}

Copyright for this article is retained by the author(s), with first publication rights granted to the journal.

This is an open-access article distributed under the terms and conditions of the Creative Commons Attribution license (http://creativecommons.org/licenses/by/4.0/). 